\title{
FORMULASI PERMEN PEREDA RADANG TENGGOROKAN DARI DAUN PECUT KUDA (Stacytarpheta jamaicensis) SEBAGAI PANGAN FUNGSIONAL
}

\section{Formulation of Throat relief Candy from Stacytarpheta jamaicensis Leaf as a Functional Food}

\author{
Vritta Amroini Wahyudi*, Puspa Seqip, Nur Sahirah, Noverita Resya \\ Jurusan Teknologi Pangan, FPP Universitas Muhammadiyah Malang \\ Jl. Raya Tlogomas 246, Malang \\ *Penulis Korespondensi, Email: vritta@umm.ac.id
}

\begin{abstract}
ABSTRAK
Daun pecut kuda (Stachytarpheta jamaicensis) merupakan tanaman dari famili Verbenaceae yang telah diteliti dan terbukti memiliki beberapa bioaktivitas seperti antimikroba, antioksidan, dan antiinflamatori. Penelitian ini bertujuan untuk memformulasi pembuatan permen pereda tenggorokan dari ekstrak daun pecut kuda sebagai langkah dukungan diversifikasi pangan fungsional. Perlakuan terbaik dipilih melalui perbandingan parameter analisis dengan SNI Permen (Kembang Gula Keras) 01-3547-2008 dan uji daya hambatnya terhadap bakteri Streptococcus pyogenes. Pada desain penelitian, terdapat penambahan perlakuan perasa daun mint untuk bentuk inovasi awal pemberian rasa alami. Formulasi yang baik dalam pembuatan permen adalah dengan penambahan $40 \%$ ekstrak daun pecut kuda dengan penambahan perasa alami daun mint $(10 \%)$. Formulasi terbaik memiliki kemampuan daya hambat sebesar $8.30 \pm 0.14 \mathrm{~mm}$ terhadap bakteri Streptococcus pyogenes dengan parameter uji kadar air $(0.36 \%)$, abu $(0.39 \%)$, dan gula reduksi $(0.74 \%)$ yang sesuai dengan SNI Permen Keras 01-3547-2008. Permen diketahui positif mengandung alkaloid, tanin, dan saponin.
\end{abstract}

Kata kunci: Antibakteri, Daun Pecut Kuda, Permen, Stachytarpheta jamaicensis.

\begin{abstract}
Stachytarpheta jamaicensis is a plant of the Verbenaceae family that have several bioactive such as antioxidants, antimicrobials, and anti-inflammatory. This research aims to formulate the throat-relieving candy from Stachytarpheta jamaicensis leaf extract as a step to support functional food diversification. The best treatment was chosen through comparison of the analysis parameters with SNI Hard Candy 01-3547-2008 and test its inhibition against Streptococcus pyogenes bacteria. In the research design, there was the addition of mint leaf flavoring treatment to the initial form of innovation giving natural flavor. The best formulation in making candy is $40 \%$ Stachytarpheta jamaicensis leaf extract with the addition of natural flavor of mint leaves (10\%). The best formulation has an inhibitory ability of $8.30 \pm 0.14 \mathrm{~mm}$ against Streptococcus pyogenes with water content test parameters $(0.36 \%)$, ash $(0.39 \%)$, and reducing sugar (0.74\%) in accordance with SNI. Hard candy is known to contain positive alkaloids, tannins, and saponins.
\end{abstract}

Keywords: Antibacterial, candy, horsewhip leaf, Stachytarpheta jamaicensis.

\section{PENDAHULUAN}

Tanaman medisinal merupakan sumber senyawa aktif yang bisa diolah sebagai pangan fungsional. Pengertian pangan fungsional menurut BPOM merupakan pangan olahan 
dengan beberapa senyawa fungsional seperti fungsi fisiologis, aman, dan memiliki manfaat untuk kesehatan, berdasarkan kajian ilmiah (BPOM, 2011). Daun beberapa tumbuhan seperti belimbing, berenuk, sirsak, gambir (Pendit dkk, 2016; Ardiati dan Kusnadi, 2014; Muizuddin dan Zubaidah, 2015; Magdalena dan Kusnadi, 2015) terbukti memiliki aktivitas antibakteri. Aktivitas yang dimiliki oleh tanaman berhubungan dengan kandungan mentabolit sekunder. Metabolit sekunder merupakan senyawa yang diproduksi tanaman secara harfiah sebagai perlindungan. Pada perjalanan keilmuan diketahui bahwa senyawa metabolit sekunder diproduksi berbeda jalur dengan metabolit primer. (Harborne, 2006).

Daun pecut kuda (Stachytarpheta jamaicensis) merupakan tanaman dari famili Verbenaceae yang telah diteliti dan terbukti memiliki beberapa bioaktivitas seperti antibakteri, antioksidan, dan antiinflamatori (Idu dkk, 2007; Ramakrishnan dkk, 2013; Joshi dkk, 2010; Meena dan Pitchai, 2011). Pecut kuda tumbuh di daerah tropis seperti Indonesia dan Amerika, serta hutan subtropis Afrika, Asia, dan Oceania (Idu, M. dkk, 2009). Daun pecut kuda secara tradisional telah digunakan sebagai obat alergi, gangguan pernafasan, pilek, batuk, demam, konstipasi, gangguan pencernaan, dan gangguan akibat menstruasi (Sivaranjani dkk, 2014). Bioaktivitas yang dimiliki daun pecut kuda berhubungan dengan fitokimia yang terkandung di dalamnya. Penelitian sebelumnya telah menyebutkan bahwa daun pecut kuda memiliki mengandung alkaloid, flavonoid, turunan glikosida, turunan fenolik, kuinon, saponin, steroid, tanin, dan terpenoid (Putera dan Shazura, 2010; Suneetha dkk, 2013, Pandian dkk, 2013, Sahoo dkk, 2014).

Potensi antibakteri pada daun pecut kuda telah diteliti dan terbukti menghambat pertumbuhan dari bakteri gram positif: Enterococcus faecalis, Micrococcus varians, Streptococcus agalactiae serta Staphylococcus aureus), serta bakteri gram negatif: (Escherichia coli, Salmonella typhimurium, Klebsiella pneumoniae, Pseudomonas aeruginosa, Serratia marcescens, serta Proteus mirabilis) (Ololade dkk, 2017). Adanya aktivitas antibakteri pada daun pecut kuda menunjukkan adanya potensi diolah lebih lanjut menjadi pangan fungsional seperti halnya permen pereda radang tenggorokan. Penyakit radang tenggorokan disebabkan karena infeksi dari Streptococcus pyogenes atau grup A Streptococcus (bisa disebut sebagai grup A strep, atau GAS) (Thangiah, 2019). Streptococcus pyogenes termasuk bakteri patogen yang banyak menginfeksi manusia. Bakteri tersebut menginfeksi manusia ketika pertahanan tubuh inang menurun kemudian menyebar sampai ke jaringan (Cunningham, 2000). Ekstrak daun pecut kuda diketahui aktif menghambat bakteri Streptococcus pyogenes dengan zona hambat $13.57 \pm 0.03 \mathrm{~mm}$, lebih besar dibandingkan dengan kontrol positif penisilin dengan zona hambat $12.97 \pm 0.03$ (Thangiah, 2019).

Penelitian ini bertujuan untuk memformulasi pembuatan permen pereda tenggorokan dari ekstrak daun pecut kuda. Permen dengan tambahan ekstrak atau biasa disebut sebagai medicated hard candy merupakan langkah dukungan diversifikasi pangan fungsional. Perlakuan terbaik dipilih melalui perbandingan parameter analisis dengan SNI Permen (Kembang Gula Keras) 01-3547-2008 (SNI, 2008) dan uji daya hambatnya terhadap bakteri Streptococcus pyogenes. Pada desain penelitian, terdapat penambahan perlakuan perasa daun mint untuk bentuk inovasi awal pemberian rasa alami. Analisis skrining fitokimia juga dilakukan terhadap ekstrak untuk mengidentifikasi jenis metabolit sekunder yang terdapat pada daun pecut kuda.

\section{BAHAN DAN METODE}

\section{Bahan}

Bahan daun pecut kuda diperoleh dari Kota Malang, Jawa timur, Indonesia. Penelitian menggunakan daun mint, akuades, gula, asam oksalat $\left(\mathrm{H}_{2} \mathrm{C}_{2} \mathrm{O}_{4}\right)$, reagen Luff, batu didih, kalium iodida $(\mathrm{KI})$, asam klorida $(\mathrm{HCl})$, asam sulfat $\left(\mathrm{H}_{2} \mathrm{SO}_{4}\right)$, asam asetat $\left(\mathrm{CH}_{3} \mathrm{COOH}\right)$, magnesium $(\mathrm{Mg})$, larutan $\alpha$-amilum, natrium hidroksida $(\mathrm{NaOH})$, etanol, $n$-heksana, dan media nutrient agar (NA). 
Alat

Penelitian menggunakan panci, pisau, oven, kompor, loyang, pengaduk, baskom, desikator, botol vial, neraca analitik, kurs porselen, spatula, pipet, kuvet, spektrofotometer UVVis Shimadzu1800, erlenmeyer, gelas beker, filler, tabung reaksi, aluminium foil, plastik wrap, vortex, pendingin tegak, Laminary Air Flow (LAF), inkubator, cawan petri, colony counter, spidol, bunsen, jarum ose, batang L, kertas saring, penggaris, lemari asam, dan hot plate.

\section{Desain Penelitian}

Penelitian menggunakan RAK sederhana (Rancangan Acak Kelompok) dengan ulangan tiga kali. Faktor terdiri dari 8 level. Kontrol ( $p c 0$ ) merupakan formulasi permen tanpa adanya tambahan ekstrak. Perlakuan pc1-pc4 dilakukan dengan penambahan konsentrasi ekstrak daun pecut kuda yang berbeda. Perlakuan pc5-pc6 dilakukan dengan penambahan ekstrak daun mint dengan konsentrasi yang sama yaitu, 10\% (v/v) sebagai bentuk uji coba awal adanya tambahan rasa.

Tabel 1. Perlakuan Pembuatan Daun Pecut Kuda

\begin{tabular}{ccc}
\hline Perlakuan & $\begin{array}{c}\text { Ekstrak Daun Pecut Kuda } \\
(\mathrm{v} / \mathrm{v})\end{array}$ & $\begin{array}{c}\text { \% Estrak Daun Mint } \\
(\mathrm{v} / \mathrm{v})\end{array}$ \\
\hline Kontrol (pc0) & 0 & 0 \\
Perlakuan 1 (pc1) & 10 & 0 \\
Perlakuan 2 (pc2) & 20 & 0 \\
Perlakuan 3 (pc3) & 30 & 0 \\
Perlakuan 4 (pc4) & 40 & 0 \\
Perlakuan 5 (pc5) & 10 & 10 \\
Perlakuan 6 (pc6) & 20 & 10 \\
Perlakuan 7 (pc7) & 30 & 10 \\
Perlakuan 8 (pc8) & 40 & 10 \\
\hline
\end{tabular}

Analisis produk permen menggunakan uji kimia proksimat antara lain kadar air (metode pengeringan oven), kadar abu (metode pengeringan oven), kadar gula total (metode anthrone), dan kadar gula reduksi (metode Luff-Schroll). Uji daya hambat permen menggunakan metode disc diffusion (tes Kirby-Bauer). Perlakuan terbaik dipilih melalui perbandingan parameter analisis dengan SNI Permen (Kembang Gula Keras) 01-3547-2008 dan uji daya hambatnya terhadap bakteri Staphylococcus pyogenes. Analisis skrining fitokimia juga dilakukan terhadap ekstrak daun pecut kuda untuk mengetahui metabolit sekunder yang terkandung di dalamnya.

\section{Tahapan Penelitian}

Tahapan pada penelitian ini antara lain, (1) ekstraksi daun pecut kuda, (2) pembuatan permen daun pecut kuda, (3) analisis produk (uji air, abu, gula reduksi, gula total) dan skrinning fitokimia (analisis kualitatif flavonoid, alkaloid, tanin, saponin, terpenoid). Pembuatan permen merujuk pada Paten "Komposisi Permen Cajuput untuk Pelega Tenggorokan" (Hanny dkk, 2000). Pembuatan permen diawali dengan ekstraksi daun pecut kuda dengan pelarut air.

\section{Metode}

Metode penelitian RAK sederhana dengan 3 ulangan, faktor terdiri dari 8 level. Faktor itu tersdiri dari perlakuan berbagai konsentrasi ekstrak daun pecut kuda yaitu dalam satuan (v/v), 10\%, 20\%, 30\%, 40\%. 


\section{Ekstraksi Daun Pecut Kuda dan Daunt Mint}

Ekstraksi daun pecut kuda dan juga daunt mint dilakukan dengan pemakaian sebanyak 500 gram. Sampel kemudian direbus dengan pelarut akuades. Pelarut akuades digunakan untuk mengestrak dengan ketentuan suhu dan waktu tertentu $\left(T=90^{\circ} \mathrm{C}, t=15\right.$ menit). Hasil rebusan kemudian didinginkan sampai diperoleh suhu kamar $\left(25^{\circ} \mathrm{C}\right)$. Ekstraksi menggunakan pelarut air karena akan diaplikasikan ke produk pangan. Konsentrasi yang digunakan pada perlakuan berbasis \%v/v.

\section{Pembuatan Permen}

Pembuatan permen merujuk pada Paten "Komposisi Permen Cajuput untuk Pelega Tenggorokan" (Hanny dkk, 2000). Pembuatan permen dilakukan dengan mencampur air, sukrosa, dan glukosa. Takaran pembuatan dapat dilihat pada Tabel 2.

Tabel 2. Komposisi Pembuatan Permen

\begin{tabular}{cccccc}
\hline Perlakuan & $\begin{array}{c}\text { Volume Air } \\
(\mathrm{mL})\end{array}$ & $\begin{array}{c}\text { Sukrosa } \\
(\mathrm{g})\end{array}$ & $\begin{array}{c}\text { Glukosa } \\
(\mathrm{g})\end{array}$ & $\begin{array}{c}\text { Ekstrak } \\
\text { Daun Pecut } \\
\text { Kuda }(\mathrm{mL})\end{array}$ & $\begin{array}{c}\text { Ekstrak } \\
\text { Daun Mint } \\
(\mathrm{mL})\end{array}$ \\
\hline Kontrol (pc0) & 100 & 200 & 100 & 0 & 0 \\
Perlakuan 1 $(\mathrm{pc} 1)$ & 90 & 200 & 100 & 10 & 0 \\
Perlakuan 2 $(\mathrm{pc} 2)$ & 80 & 200 & 100 & 20 & 0 \\
Perlakuan 3 (pc3) & 70 & 200 & 100 & 30 & 0 \\
Perlakuan 4 (pc4) & 60 & 200 & 100 & 40 & 0 \\
Perlakuan 5 (pc5) & 90 & 200 & 100 & 10 & 10 \\
Perlakuan 6 (pc6) & 80 & 200 & 100 & 20 & 10 \\
Perlakuan 7 (pc7) & 70 & 200 & 100 & 30 & 10 \\
Perlakuan 8 (pc8) & 60 & 200 & 100 & 40 & 10 \\
\hline
\end{tabular}

Campuran air, sukrosa, dan glukosa kemudian dipanaskan sampai suhu $100^{\circ} \mathrm{C}$ selama 15 menit. Setelah mendidih, ekstrak ditambahkan sesuai dengan Tabel 2. Pemanasan berlanjut sampai suhu $140-150^{\circ} \mathrm{C}$ sehingga campuran membuih dan mengental. Campuran yang dihasilkan kemudian dituangkan ke dalam cetakan. Proses pencetakan dilakukan pada suhu kamar. Setelah campuran mengeras, permen dilepaskan dari cetakan.

\section{Prosedur Analisis}

Analisis produk permen antara lain uji proksimat yaitu, kadar air (pengeringan dengan oven), kadar abu (pengeringan dengan oven), kadar gula total (metode anthrone), kadar gula reduksi (metode Luff-Schroll), uji daya hambat (metode disc diffusion / tes Kirby-Bauer) terhadap bakteri Staphylococcus pyogenes.Perlakuan terbaik dipilih melalui perbandingan parameter analisis dengan SNI Permen (Kembang Gula Keras) 01-3547-2008.

\section{Uji Proksimat Permen}

Uji Kadar Air

Sebanyak 5 gram sampel permen dihaluskan menggunakan mortal martil, kemudian dimasukkan dalam botol vial yang telah ditimbang dan distandarisasi dengan desikator. Botol vial dimasukkan ke dalam oven (5-6 jam). Botol vial kemudian didinginkan pada desikator dan ditimbang kembali. Rumus perhitungan kadar air :

$$
\text { Kadar air }=\frac{\text { massa } \operatorname{air}(\mathrm{g})}{\text { massa sampel-massa } \operatorname{air}(\mathrm{g})} \times 100 \%
$$

\section{Uji Kadar Abu}

Sebanyak $5 \mathrm{~g}$ sampel permen dihaluskan menggunakan mortal martil. Permen yang sudah dihaluskan. Sampel dipindahkan ke cawan porselen. Pengabuan dilakukan dengan tanur suhu $600^{\circ} \mathrm{C}$ selama 24 jam. Hasil pengabuan didiamkan terlebih dahulu pada desikator. 
Rumus :

$$
\text { Kadar abu }(\%)=\frac{\text { massa sampel akhir }- \text { massa cawan kosong }(\mathrm{g})}{\text { massa sampel awal }(\mathrm{g})} \times 100 \%
$$

Uji Kadar Gula Total (Metode Anthrone)

Sampel sebanyak $2 \mathrm{~g}$ dihaluskan dan diencerkan dengan $250 \mathrm{~mL}$ akuades kemudian ditambahkan reagen anthrone (penambahan cepat). Tabung kemudian dipanaskan dengan waterbath selama 12 menit. Setelah mendidih, tabung reaksi didingankan dengan cepat menggunakan air mengalir. Campuran kemudian diuji intensitas warnanya dengan spektro UV-Vis. Campuran dipipet ke kuvet kemudian diukur intensitas warnanya melalui absorbansi dengan spektroskopi UV-Vis (pengukuran pada $630 \mathrm{~nm}$ ). Absorbansi dari larutan standar digunakan untuk mendapatkan persamaan regresi. Persamaan regresi kemudian digunakan untuk menghitung total gula sampel.

\section{Uji Kadar Gula Pereduksi (Metode Luff Schrool)}

Sampel sebanyak $5 \mathrm{~g}$ ditimbang kemudian dimasukkan ke erlenmeter. Sampel ditambahkan larutan $200 \mathrm{ml} \mathrm{HCl} \mathrm{3 \%} \mathrm{kemudian} \mathrm{didihkan} \mathrm{(waktu} \mathrm{pendidihan} \mathrm{kurang} \mathrm{lebih} 1$ jam). Campuran ditambahkan $\mathrm{NaOH} 30 \%$ dan $\mathrm{CH}_{3} \mathrm{COOH} 3 \%$. Campuran kemudian dipindahkan ke labu ukur, ditambahkan reagen Luff Schrool sebanyak $25 \mathrm{ml}$ dan akuades sebanyak $15 \mathrm{ml}$. Campuran dididihkan selama 10 menit kemudian didinginkan dengan cepat menggunakan air mengalir. Setelah dingin, campuran dititrasi dengan larutan KI $20 \%$ menggunakan indikator amilum. Titrasi dihentikan sampai warna biru hilang. Volume yang diperoleh dicocokan dengan Tabel Luff Schrool dan dihitung persen gula reduksinya.

\section{Uji Daya Hambat Permen terhadap Bakteri Streptococcus pyogenes}

Aktivitas antibakteri diuji dengan disc diffusion (Kirvy-Bauser Methode). Ose disetrilkan, dimasukkan ke dalam tabung reaksi suspensi bakteri kemudian dioleh ke media yang telah berisi Nutritien Agar (NA). Olesan dibiarkan sampai mengering. Paper disk diameter $6 \mathrm{~mm}$ direndam dengan ekstrak daun pecut kuda selama 1 jam. Setelah direndam, ditiriskan, lalu ditempelkan di atas media yang telah diolesi bakteri. Media yang telah berisi olesan bakteri dan tambahan ekstrak daun pecut kuda, diinkubasi $37^{\circ} \mathrm{C}$ selama 48 jam. Hasil positif (artinya positif antibakteri) dengan terbentuk zona bening (zona hambat).

\section{Analisis Proksimat}

\section{HASIL DAN PEMBAHASAN}

\section{Analisis Kadar Air Permen Formulasi}

Hasil uji analisis kadar air dari permen formulasi ekstrak daun pecut kuda penelitian ini, tercantum pada Gambar 1.

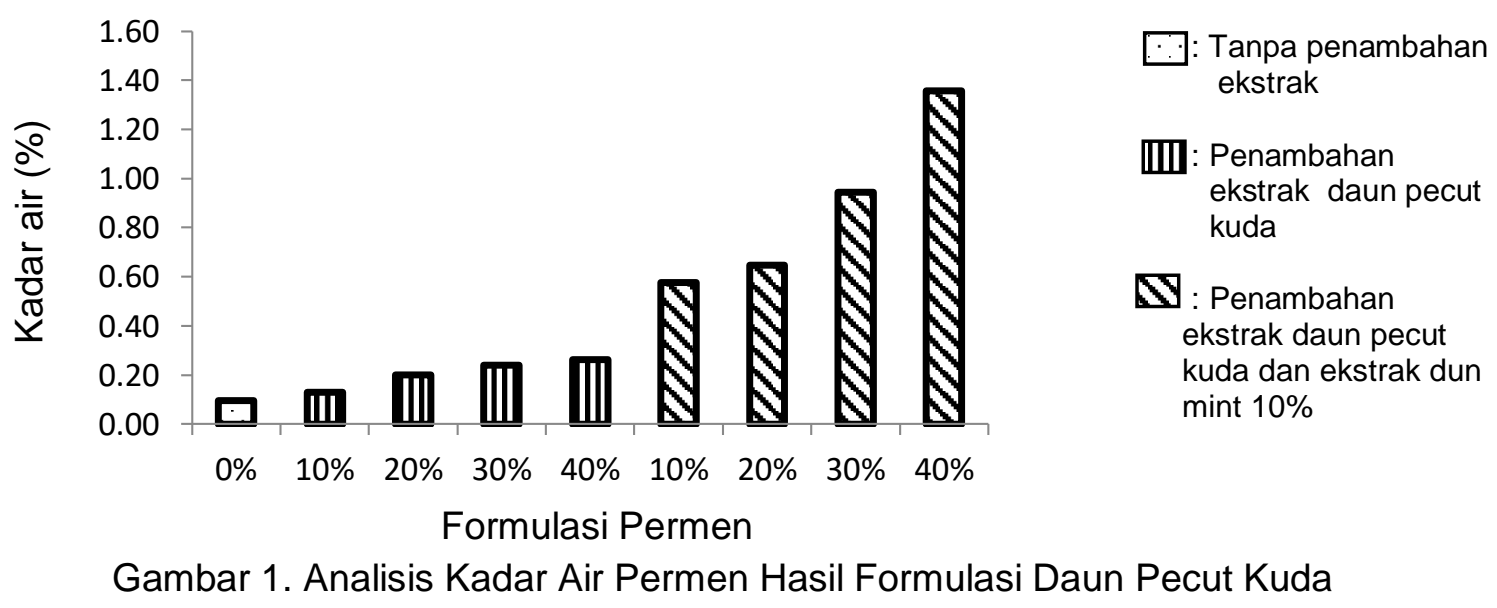

Kadar air (uji kuantitatif) menjadi parameter permen karena berhubungan dengan masa penyimpanan. Semakin rendah kadar air yang dimiliki, daya tahan dan masa 
penyimpanan permen tersebut semakin lama. Kandungan air permen formulasi pada penelitian ini (Gambar 1) adalah $0.10-1.36 \%$. Semakin tinggi konsentrasi penambahan ekstrak pecut kuda dan mint, didapatkan kandungan kadar air permen permen pecut kuda yang semakin tinggi. Nilai kadar air maksimal yang disyaratkan dalam SNI (SNI, 2008) adalah $3.50 \%$. Berdasarkan hasil uji kadar air, diketahui bahwa semua perlakuan sesuai dengan standar SNI.

\section{Analisis Kadar Abu Permen Formulasi}

Gambar 2 menunjukkan hasil uji analisis kadar abu dari permen ekstrak daun pecut kuda dan juga dengan penambahan mint.

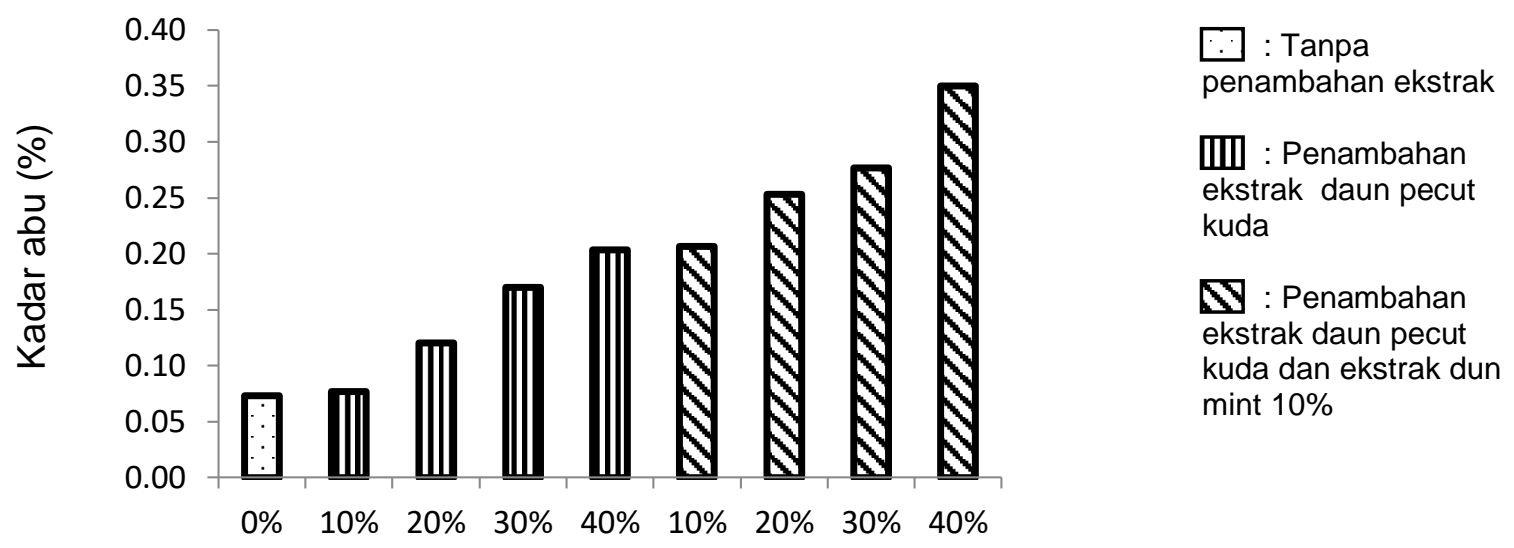

Gambar 2. Analisis Kadar Abu Permen Hasil Formulasi Daun Pecut Kuda

Kadar abu menunjukkan sisa hasil pembakaran senyawa organik suatu sampel (Winarno, 2008). Kadar abu menunjukkan kadar mineral atau senyawa anorganik. Parameter kadar abu pada permen berpengaruh pada penampakan dari permen yang dihasilkan. Semakin rendah kandungan abu maka tampilan permen semakin baik karena menghasilkan warna yang makin jernih (Smidova, 2003).

Berdasarkan Gambar 2, semakin banyak penambahan ekstrak daun pecut kuda dan ekstrak daun mint dihasilkan kadar abu semakin tinggi. Hal itu dikarenakan ekstrak daun pecut kuda dan ekstrak daun mint mengandung mineral sehingga peningkatan kosentrasi ekstrak, kadar abu semakin tinggi. Menurut SNI kadar abu maksimal pada permen sebesar $2.0 \%$ (SNI, 2008). Berdasarkan hasil analisis, semua perlakuan tergolong aman, sesuai dengan standar SNI.

\section{Analisis Gula Reduksi Permen Hasil Formulasi}

Hasil analisis kadar gula reduksi permen ekstrak daun pecut kuda dengan penggunaan berbagai konsentrasi dan penambahan ekstrak daun mint dapat dilihat pada Gambar 3. Semakin tinggi konsentrasi ekstrak maka gula reduksi semakin rendah. Kadar gula reduksi mempengaruhi sifat higroskopis dari permen yang dihasilkan. Semakin banyak gula reduksi yang terbentuk maka gula yang dihasilkan akan bersifat higroskopis, atau mudah menyerap udara maupun air dari luar. Permen dengan gula reduksi tinggi, cenderung bersifat higroskopis sehingga rawan lengket (Smidova, 2003). Menurut SNI kadar gula reduksi maksimal pada permen sebesar $24 \%$ (SNI, 2008). Formulasi permen menunjukkan kadar gula reduksi yang sesuai dengan SNI. 


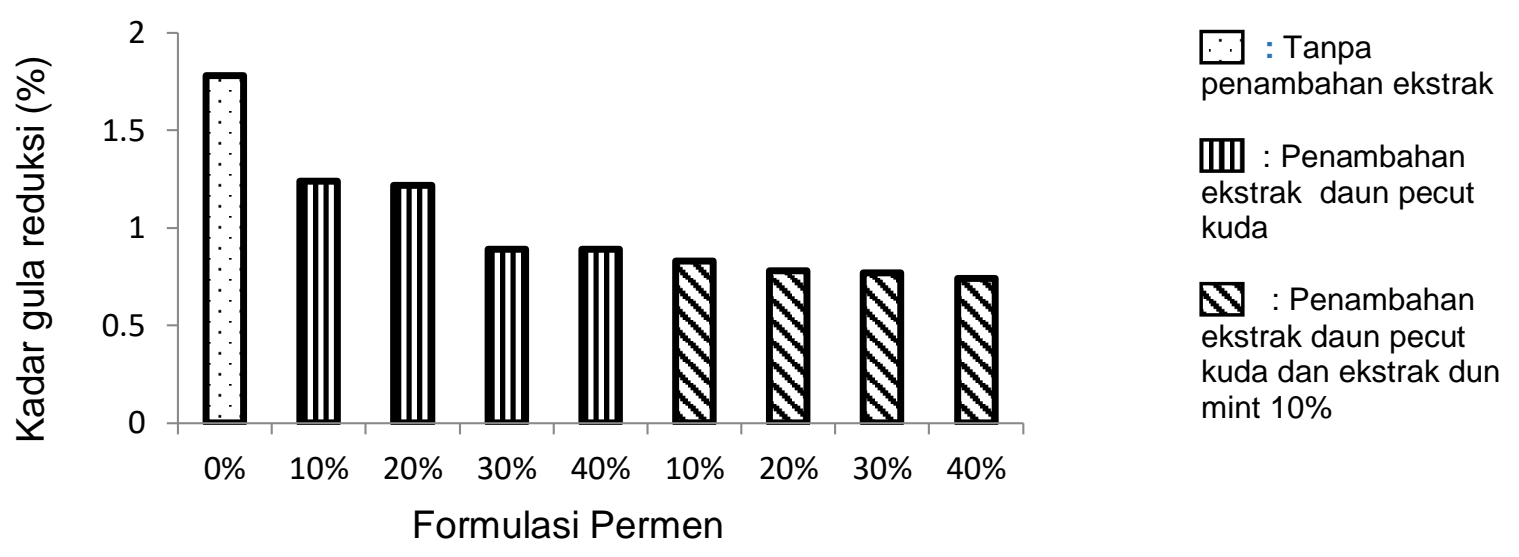

Gambar 3. Analisis Kadar Gula Reduksi Hasil Formulasi Daun Pecut Kuda

\section{Analisis Gula Total Permen Hasil Formulasi}

Rerata kadar gula total permen esktrak daun pecut kuda dengan penggunaan berbagai konsentrasi dan penambahan esktrak daun mint dapat dilihat pada Gambar 4.

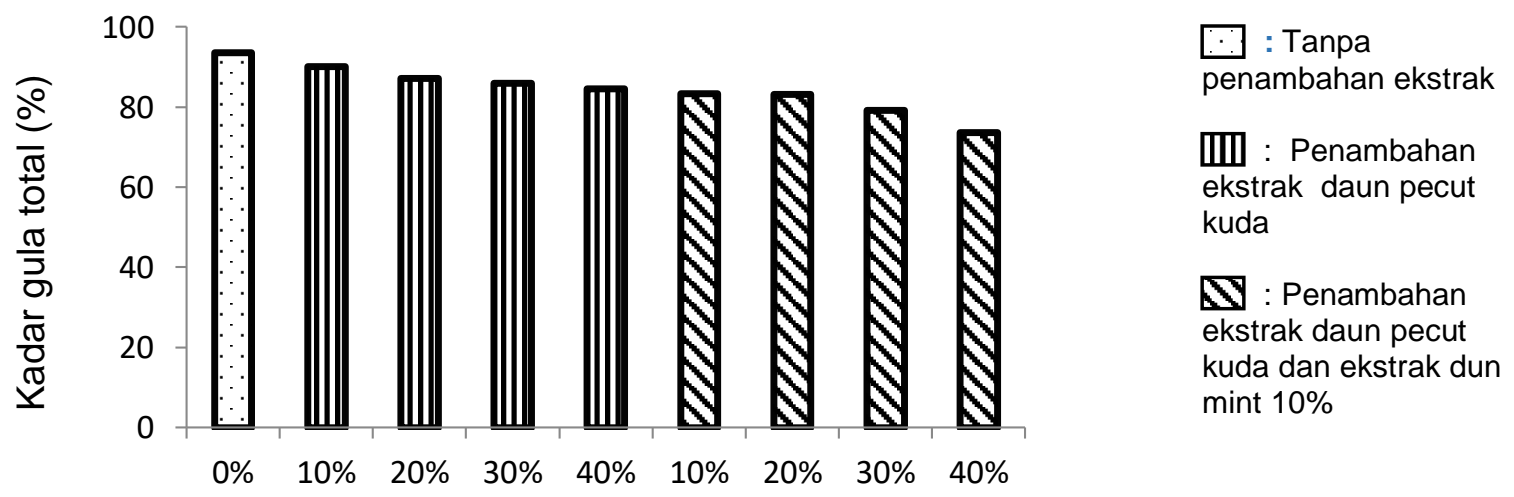

Formulasi Permen

Gambar 4. Analisis Kadar Gula Total Hasil Formulasi Daun Pecut Kuda

Berdasarkan Gambar 4, semakin tinggi konsentrasi esktrak daun pecut kuda, semakin rendah kadar gula total nya. Hal ini berhubungan dengan volume air yang digunakan (Tabel 2). Pada perlakuan konsentrasi (\%v/v), volume air menurun seiring bertambahnya konsentrasi ekstrak (Tabel 2). Penurunan kadar air selaras dengan penurunan jumlah padatan total terlarut. Total padatan terlarut berhubungan dengan total gula. Hal ini dikarenakan kadar gula total merupakan bagian dari total padatan terlarut itu sendiri (Winarno, 2008). 


\section{Uji Daya Hambat Permen Hasil Formulasi}

Tabel 3 Hasil Uji Daya Hambat Permen Formulasi Daun Pecut Kuda.

\begin{tabular}{ccc}
\hline Perlakuan & Daya Hambat $(\mathrm{mm})$ & $\begin{array}{c}\text { Kesimpulan } \\
\text { Uji Daya Hambat }\end{array}$ \\
\hline Kontrol $(\mathrm{pc0})$ & $4.10^{\mathrm{a}} \pm 0.15$ & Lemah \\
Perlakuan 1 $(\mathrm{pc} 1)$ & $4.40^{\mathrm{b}} \pm 0.10$ & Lemah \\
Perlakuan 2 $(\mathrm{pc} 2)$ & $4.50^{\mathrm{c}} \pm 0.10$ & Lemah \\
Perlakuan 3 $(\mathrm{pc} 3)$ & $5.10^{\mathrm{d}} \pm 0.10$ & Sedang \\
Perlakuan 4 $(\mathrm{pc} 4)$ & $5.20^{\mathrm{e}} \pm 0.15$ & Sedang \\
Perlakuan 5 $(\mathrm{pc5})$ & $5.50^{\mathrm{f}} \pm 0.15$ & Sedang \\
Perlakuan 6 $(\mathrm{pc6})$ & $6.30^{\mathrm{g}} \pm 0.13$ & Sedang \\
Perlakuan 7 $(\mathrm{pc} 7)$ & $8.20^{\mathrm{h}} \pm 0.12$ & Sedang \\
Perlakuan 8 $(\mathrm{pc8})$ & $8.30^{\mathrm{i}} \pm 0.14$ & Sedang \\
\hline
\end{tabular}

Berdasarkan Tabel 3, semakin tinggi konsentrasi ekstrak daun pecut kuda, semakin besar aktif daya hambat antibakterinya (terlihat pada besarnya diameter zona hambat). Standar hasil aktivitas antibakteri dari uji ini yaitu, diameter zona hambat $<5 \mathrm{~mm}$ artinya lemah, 5-10 mm artinya sedang, 10-20 mm artinya kuat (Davis dan Stout, 1971). Hasil penelitian menunjukkan bahwa perlakuan p1-p8 tergolong sedang. Penelitian sebelumnya hanya menguji ekstrak daun pecut kuda (bukan dalam bentuk produk) dengan zona hambat $13.57 \pm 0.03 \mathrm{~mm}$ terhadap bakteri Streptococcus pyogenes, lebih besar dibandingkan dengan kontrol positif penisilin dengan zona hambat $12.97 \pm 0.03$ (Thangiah, 2019). Besarnya zona hambat dipengaruhi oleh metabolit sekunder yang dimiliki (Brock, 1988).

\section{Skrining Fitokimia}

Ekstrak daun pecut kuda dengan pelarut akuades dianalisis secara kualitatif untuk mengetahui keberadaan metabolit sekunder. Hasil skrining dapat dilihat pada Tabel 4.

Tabel 4. Hasil Skrinning Fitokimia Ekstrak Daun Pecut Kuda

\begin{tabular}{|c|c|c|}
\hline Golongan & Hasil & Keterangan \\
\hline Flavonoid & Negatif (-) & Adanya perubahan warna menjadi merah bata, merah tua \\
\hline Alkaloid & Positif $(+)$ & Adanya endapan putih (Meyer) \\
\hline & Positif $(+)$ & Adanya endapan jingga (Dragendorf) \\
\hline Tanin & Positif $(+)$ & $\begin{array}{l}\text { Perubahan warna menjadi hijau kehitaman, coklat } \\
\text { kehitaman, biru kehitaman }\end{array}$ \\
\hline Terpenoid & Negatif $(-)$ & Adanya perubahan warna menjadi hijau kebiruan \\
\hline Saponin & Positif $(+)$ & Terbentuknya busa permanen \\
\hline
\end{tabular}

Hasil uji skrining fitokimia ekstrak daun pecut kuda dengan pelarut akuades menunjukkan bahwa kandungan yang terdapat didalamya yaitu alkaloid, tanin dan saponin. Penelitian sebelumnya telah menyebutkan bahwa daun pecut kuda memiliki mengandung alkaloid, flavonoid, turunan glikosida, turunan fenolik, kuinon, saponin, steroid, tanin, dan terpenoid (Putera dan Shazura, 2010; Suneetha dkk, 2013, Pandian dkk, 2013, Sahoo dkk, 2014).

Uji bioaktivitas yang dihubungankan interpretasinya dengan senyawa metabolit sekunder pada tanaman perlu dilakukan untuk menganalisis potensi terjadinya keracunan dan juga efek samping yang tidak diinginkan (Hernani, 2011 dan Hendra dkk, 2011). Daun pecut kuda memiliki kandungan alkaloid, tanin, dan saponin pada daun pecut kuda berhubungan dengan aktivitas antibakteri yang dihasilkan. Mekanisme antibakteri karena senyawa alkaloid, tanin, dan saponin berhubungan dengan kemampuan senyawa tersebut merusak materi 
genetik bakteri (Nuria dkk, 2009; Harborne, 2006; Darsana dkk, 2012; Hernani dkk, 2011; dan Hendra dkk, 2011.)

\section{Formulasi Terbaik}

Pemilihan formulasi terbaik dilakukan dengan membandingkan parameter uji dengan SNI Permen (Kembang Gula Keras) 01-3547-2008 (SNI, 2008) dan uji daya hambatnya terhadap bakteri Staphylococcus pyogenes. Data SNI Permen tercantum pada Tabel 5.

Tabel 5. SNI Permen Keras 01-3547-2008

\begin{tabular}{clcc}
\hline No. & \multicolumn{1}{c}{ Kriteria } & Satuan & Persyaratan \\
\hline 1 & Keadaan & & \\
1.1 & Bau & & Normal \\
1.2 & Rasa & $\%$ & Normal \\
2 & Kadar Air & $\%$ & Maks 3.5 \\
3 & Kadar Abu & $\%$ & Maks 2.0 \\
4 & Gula Reduksi & $\%$ & Maks 24 \\
5 & Sakarosa & & Min 35 \\
6 & Cemaran Logam & $\mathrm{mg} / \mathrm{kg}$ & \\
6.1 & Timbal (Pb) & $\mathrm{mg} / \mathrm{kg}$ & Maks 2.0 \\
6.2 & Tembaga (Cu) & $\mathrm{mg} / \mathrm{kg}$ & Maks 2,0 \\
6.3 & Timah (Sn) & $\mathrm{mg} / \mathrm{kg}$ & Maks 0.03 \\
6.4 & Raksa (Hg) & & Maks 1.0 \\
7 & Cemaran Arsen (As) & & \\
8 & Cemaran Mikroba & $\mathrm{koloni} / \mathrm{g}$ & Maks $5.10^{2}$ \\
8.1 & Angka Lempeng Total & $\mathrm{APM} / \mathrm{g}$ & Maks 20 \\
8.2 & Bakteri coliform & APM $/ \mathrm{g}$ & Min 3 \\
8.3 & E. coli & $\mathrm{koloni} / \mathrm{g}$ & Maks $1.10^{2}$ \\
8.4 & Staphyllococcus aureus & & Negatif $25 \mathrm{~g}$ \\
8.5 & Salmonella & $\mathrm{koloni} / \mathrm{g}$ & Maks $1.10^{2}$ \\
8.6 & Kapang/ khamir & &
\end{tabular}

Sumber : SNI, 2008

Berdasarkan data SNI, parameter uji proksimat seperti kadar air, abu, gula reduksi dibandingkan. Hasil uji daya hambat digunakan sebagai parameter penentuan tersebut. Perbandingan tercantum Tabel 6 . Hasil perbandingan menghasilkan formulasi penambahan $40 \%$ ekstrak daun pecut kuda dengan penambahan rasa alami daun mint (10\%).

Tabel 6. Hasil Tabel Bandingan Parameter Hasil Penelitian dan SNI

\begin{tabular}{cccccc}
\hline $\begin{array}{c}\text { Formulasi(v/v) } \\
\text { daun pecut kuda }\end{array}$ & $\begin{array}{c}\text { Kadar Gula } \\
\text { Reduksi }(\%)\end{array}$ & $\begin{array}{c}\text { Kadar Air } \\
(\%)\end{array}$ & $\begin{array}{c}\text { Kadar } \\
\text { Abu }(\%)\end{array}$ & SNI & $\begin{array}{c}\text { Uji Daya } \\
\text { Hambat } \\
(\mathrm{mm})\end{array}$ \\
\hline $0 \%$ & 1.78 & 0.10 & 0.05 & sesuai & $4.10 \pm 0.15$ \\
$10 \%$ & 1.24 & 0.13 & 0.05 & Sesuai & $4.40 \pm 0.10$ \\
$20 \%$ & 1.22 & 0.24 & 0.09 & Sesuai & $4.50 \pm 0.10$ \\
$30 \%$ & 0.89 & 0.57 & 0.19 & Sesuai & $5.10 \pm 0.10$ \\
$40 \%$ & 0.89 & 0.65 & 0.21 & Sesuai & $5.20 \pm 0.15$ \\
$10 \%$ + daun mint & 0.83 & 0.94 & 0.28 & Sesuai & $5.50 \pm 0.15$ \\
$20 \%$ + daun mint & 0.78 & 0.20 & 0.09 & Sesuai & $6.30 \pm 0.13$ \\
$30 \%$ + daun mint & 0.77 & 0.26 & 0.12 & Sesuai & $8.20 \pm 0.12$ \\
$40 \%$ + daun mint & 0.74 & 0.36 & 0.39 & sesuai & $8.30 \pm 0.14$ \\
\hline
\end{tabular}




\section{SIMPULAN}

Formulasi yang baik dalam pembuatan permen adalah dengan penambahan $40 \%$ ekstrak daun pecut kuda dengan penambahan perasa alami daun mint (10\%). Formulasi terbaik memiliki kemampuan daya hambat sebesar $8.30 \pm 0.14 \mathrm{~mm}$ terhadap bakteri Streptococcus pyogenes dengan parameter uji kadar air $(0.36 \%)$, abu (0.39\%), dan gula reduksi (0.74\%) yang sesuai dengan SNI Permen Keras 01-3547-2008. Permen diketahui positif mengandung alkaloid, tanin, dan saponin.

\section{DAFTAR PUSTAKA}

Ardianti, A. dan Kusnadi, J. 2014. Ekstraksi Antibakteri dari Daun Berenuk (Crescentia cujete Linn.) Menggunakan Metode Ultrasonik. J Pangan dan Agroindustri 2(2), 28-35.

BPOM. 2011. Peraturan BPOM Nomor 03.1.23.11.11.09909 Tahun 2011.

Brock, T.D. 1988. Biology of Microorganisms (Ed. 6). New Jersey. Prentice Hall, Englewood Cliffs.Cunningham, M.W., Phatogenesis of Group A Streptococcal Infection, Clin Microbiol Rev.13 (3), 2000, 470-511

Darsana, I. Besung, I., dan Mahatmi, H. 2012. Potensi Daun Binahong (Anredera Cordifolia (Tenore) Steenis) dalam Menghambat Pertumbuhan Bakteri Escherichia coli secara In Vitro. Indonesia Med Veterinus 1 (3), 337-351.

Davis, W.W and Stout, T.R. 1971. Disc Plate Methods of Microbiological Antibiotic Assay. Applied Microbiol 22 (4), 659-665.

Hanny, W., Halimah, Kindly, Fahim. 2000. Komposisi Permen Cajuput untuk Pelega Tenggorokan. Republik Indonesia. ID 0000385S.

Harborne, J. B. 2006. Metode Fitokimia (Ed. 2). Bandung. Penerbit ITB.

Hendra R, Ahmad S, Sukari, A, Shukor, MY, and Oskoueian, E. 2011. Flavonoid analyses and antimicrobial activity of various parts of Phaleria macrocarpa (Scheff.) Boerl fruit. Int $J$ Mol Scie. 12, 3422-3431.

Hernani. 2011. Pengembangan Biofarmaka Sebagai Obat Herbal Untuk Kesehatan. Buletin Teknologi Pascapanen Pertanian 7 (1), 20-29.

Idu, M., Omogbai, E. K. I., Aghimien, E., Amachina, F., Timothy, O., and Omonigho, S. E. 2007. Preliminary phytochemistry, antimicrobial properties and acute toxicity of Stachytarpheta jamaicensis (L.) Vahl. leaves. Trends Med Res 2(4), 193-198.

Idu, M., Erhabor, J. O., and Odia, E. A. 2009. Morphological and anatomical studies of the leaf and stem of some medicinal plants: Stachytarpheta jamaicensis (L.) Vahl. and S. cayennensis (LC Rich) schau. Ethnobotanical Leaflets 13 (11), 1417-1425.

Joshi, V., Sutar, P., Patil, S., Gopalakrisna, B., and Sureban, R. 2010. Intl J Res Ayuverda Phar 1(1), 174-179.

Magdalena, N. V. dan Kusnadi, J. 2015. Antibakteri dari Ekstrak Kasar Daun Gambir (Uncaria Gambir var Cubadak) Metode Microwave-Assisted Extraction terhadap Bakteri Patogen. J Pangan Agroindustri 3(1) : 124-135.

Meena, R. and Pitchai, R. 2011. Evaluation if antimicrobial activity and preliminary phytochemical studies on whole plant of Starchytarpheta jamaicensis (L.) Vahl. Intl Res J Phar 2 (3), 234-239.

Muizuddin, M. dan Zubaidah, E. 2015. Studi Aktivasi Antibakteri Kefir The Daun Sirsak (Annona Muricata Linn.) dari Berbagai Merk The Daun Sirsak di Pasaran. J Pangan Agroindustri 3(4), 1662-1672

Nuria, C, M., Faizaitun, A, dan Sumantri. 2009. Uji Aktivitas Antibakteri Ekstrak Etanol Daun Jarak Pagar (Jatropha Curcas L.) Terhadap Bakteri Staphylococcus aureus ATCC 25923, Escherichia coli ATCC 25922, dan Salmonella typhi ATCC 1408. Mediagro 5 (2), 26-37. 
Ololade, Z. S., Ogunmola, O.O, Kuyooro, S.E., and Abiona, O.O. 2017. Stachytarpheta jamaicensis leaf extract: Chemical composition, antioxidant, anti-arthritic, antiinflammatory and bactericidal potentials. J Scie Innovative Res 6(4), 119-125.

Pandian, C. Srinivasan, A., and Pelapolu, C. 2013. Evaluation of wound healing activity of hydroalcoholic extract of leaves of Stachytarpheta jamaicensis in streptozotocin induced diabetic rats. Der Pharmacia Lettre 5 (2), 193-200.

Pendit, P. A. D., Zubaidah, E., dan Sriheflyna, F. H. 2016. Karakteristik Fisik-Kimia dan Aktivitas Antibakteri Ekstrak Daun Belimbing Wuluh. J Pangan Agroindustri 4(1), 400409.

Putera, I dan Shazura, K. A. 2010. Antimicrobial activity and cytotoxic effects of Stachytarpheta jamaicensis (L.) Vahl crude plant extracts [Master dissertation]. Universiti Teknologi Malaysia.

Ramakrishnan, R. and Sivaranjani, R. 2013. Pharmacognostical and phytochemical studies on stem of Stachytarpheta jamaicensis (L) Vahl. Intl Res J Phar 4 (10), 44-47.

Sahoo, S. R. and Bhatnagar, S. 2014. Phytochemical screening and bioevaluation of medicinal plant Stachytarpheta indica (L.) Vahl. Phar \& Toxicology Research. 1 (2), 15.

Sivaranjani, R., Ramakrishnan, K., dan Bhuvaneswari, G. 2014. Pharmacognostic studies on root of Stachytarpheta jamaicensis. Int Letters Nat Scie 8 (2), 100-105.

Standar Nasional Indonesia. 2008. SNI Permen (Kembang Gula Keras) 01-3547-2008.

Smidova, I., Copikova, J., Maryska, M., and Coimba, M. A. 2003. Crystals in Hard Candies. Czech J Food Scie 21 (5) : 185-191.

Suneetha, P., Poornima, S., Sumana, K., Nidhi, H., and Puttaraju, H. P. 2013. Comparative studies on antimicrobial and antifungal efficacy from Bixa Orellana L., Lantana Camara L., Stachytarpheta jamaicensis (L.)Vahl., Hyptis Suaveolens (L.) poit.With triclosan. CIB Tech J Microbiol 2 (2), 15-23.

Thangiah, A. S. 2019. Phytochemical Screening and Antimicrobial Evaluation of EthanolicAqua Extract of Stachytarpheta jamaicensis (L.) Vahl Leaves Againts Some Selected Human Pathogenic Bacteria. Rasayan J Chem 12 (1), 300-307.

Winarno, F. G. 2008. Kimia Pangan dan Gizi. Jakarta. Gramedia. 